\begin{tabular}{ccc|} 
ISSN = 1980-993X - doi:10.4136/1980-993X \\
www.ambi-agua.net \\
E-mail: ambi-agua@agro.unitau.br \\
Tel.: (12) 3625-4212
\end{tabular}

\title{
Temporal variability of the water requirement and productivity for irrigated maize crop
}

\author{
(http://dx.doi.org/10.4136/ambi-agua.185) \\ Camilo de Lelis Teixeira de Andrade ${ }^{1}$, Tales Antônio Amaral ${ }^{2}$, \\ Maria Emília Borges Alves ${ }^{3}$, Denise Freitas Silva ${ }^{4}$ \\ ${ }^{1}$ Agricultural Engineer, Ph.D. Irrigation Engineering, Researcher, Embrapa Maize and Sorghum, \\ e-mail: camilo@cnpms.embrapa.br, \\ ${ }^{2}$ Biologist, M.Sc. Plant Physiology, D.Sc Candidate UFPEL, \\ e-mail: tales_aamaral@yahoo.com.br, \\ ${ }^{3}$ Agr. Eng., D.Sc. Agr. Meteorology, FAPEMIG Research Fellow at Embrapa Maize and Sorghum, \\ e-mail: mebalves@hotmail.com., \\ ${ }^{4}$ Agr. Eng., D.Sc. Water and Env. Resources, CNPq/PNPD Res. Fellow at Embrapa Maize and Sorghum, \\ e-mail: denise@cnpms.embrapa.br,
}

\begin{abstract}
There is a worldwide effort to produce food with less water consumption, due to scarcity trend of this resource. The study aimed to evaluate water productivity, simulated by the decision support model CSM-CERES-Maize, for irrigated maize sown at different dates. Simulations were made based on management conditions of Riacho's Farm, located in Matozinhos, Minas Gerais State, Brazil. One observed large seasonal and interannual amplitude on crop water requirement and water productivity values. The highest water productivity values of 1.73 to $1.81 \mathrm{kgm}^{-3}$ were observed between February $6^{\text {th }}$ and $27^{\text {th }}$, a period that coincides with recommended maize crop sowing window in region. The simulation model proved to be a useful tool for planning and optimizing water resources use.
\end{abstract}

Keywords: Water use efficiency; simulation; DSSAT; Zea mays L..

\section{Variabilidade temporal do requerimento e da produtividade da água para a cultura do milho irrigado}

\section{RESUMO}

Há um esforço mundial para se produzir alimento com menor consumo de água, devido à tendência de escassez desse recurso. Objetivou-se, com este trabalho, avaliar a produtividade da água, simulada pelo modelo de suporte à decisão CSM-Ceres-Maize, para a cultura do milho irrigado, semeado em diferentes datas. As simulações foram realizadas para as condições de manejo da Fazenda do Riacho, localizada no município de Matozinhos, MG, Brasil. Observou-se grande amplitude sazonal e interanual nos valores do requerimento de água da cultura e da produtividade da água. Os maiores valores de produtividade da água de 1,73 a $1,81 \mathrm{kgm}^{-3}$ foram observados entre 06 e 27 de fevereiro, período que coincide com a janela recomendada para semeadura da cultura na região. O modelo de simulação demonstrou ser uma ferramenta útil para o planejamento e otimização do uso dos recursos hídricos.

Palavras-chave: Eficiência do uso da água; simulação; DSSAT; Zea mays L.. 


\section{INTRODUCTION}

Irrigation management consists of applying the required water amount to plants at the right time. When an irrigation control method is not adopted, farmers may over irrigate, fearing that crop might suffers water stress or under irrigate, especially when water has to be pumped. Excess water application causes energy and water waste and sometimes nutrients leaching and environment contamination. On the other hand, under irrigation may impose to crop some unnecessary stress that can affect yield. According to a study carried out by CEMIG, the State of Minas Gerais Power Company (Cemig, 1993), should irrigation be rationally used about $20 \%$ of water and $30 \%$ of energy consumption would be saved. Twenty percent of energy savings is due to unnecessary water application and $10 \%$ due to irrigation equipment resizing.

Efforts have been made to produce more food with less water or to increase water use efficiency. Under irrigated conditions there are some strategies that can be employed to improve efficiency, such as reducing irrigation frequency (Cardoso et al., 2004) and imposing some moderate water stress to crops. Water productivity is an indicator that can be used to evaluate water use efficiency based on various parameters, such as, grain yield or profitability per unit volume of water applied, used or evapotranspired by crop. Pereira (2003) defines water productivity as the relation between the quantity of product or service produced to the water volume used. He also states that this indicator allows the comparison of service and production processes of similar nature in terms of water demand and clarifies on their ability to save and conserve water.

Some studies have reported maize water productivity values determined with field data (Andrade et al., 2004; Mishra et al., 2001; Zhang, 2003), including an extensive literature review on the topic conducted by Zwart and Bastiaanssen (2004). However, these studies usually are punctual and do not reflect the effects of temporal climate variability on crop water requirement and yield and, hence, on water use efficiency. Modeling is a good approach to look at that kind of problem since it allows the use of weather data set to evaluate climate variability effects on crop on those traits.

This study aimed to evaluate temporal variability of crop water requirement and water productivity for irrigated maize sown at different dates.

\section{MATERIAL AND METHODS}

The study was based on the analysis of simulated crop management scenarios, done with the seasonal tool of the CSM-CERES-Maize, which is one component of the Decision Support System for Agrotechnology Transfer, DSSAT, version 4.5 (Hoogenboom et al., 2010).

The model was previously parameterized for the single cross hybrid, DKB 390YG, using data from a field trial carried out at Embrapa Maize and Sorghum experimental station (Santana et al., 2010). Model's predictive capability was also verified by using some yield and irrigation data from Riacho's Farm (Amaral et al., 2011). The farm is located in Matozinhos, Minas Gerais State, Brazil, coordinates 19 24 '32.69" South and 43 $59^{\circ} 10.34$ " West, and dedicates to dairy production. Maize is grown for silage and grain using center pivot irrigation systems to supplement rainfall.

Samples of the Red Oxisol profile, with replications, were collected at the 45 ha center pivot area for laboratory soil characteristic determinations and used later as model's input. Detailed farm data description can be found in Amaral et al. (2011). Daily data on 
ANDRADE, C. de L. T. de; AMARAL, T. A.; ALVES, M. E. B.; SILVA, D. F. Temporal variability of the water requirement and productivity for irrigated maize crop. Ambi-Agua, Taubaté, v. 6, n. 2, p. 54-60, 2011. (doi:10.4136/ambi-agua.185)

precipitation, maximum and minimum air temperature and sunshine hours containing 46 years of records were obtained at Embrapa Maize and Sorghum experimental station, located $36 \mathrm{~km}$ far from the farm.

The model was set to simulate a virtual experiment containing 52 treatments, which were weekly sowing dates. Maize crop management was set to emulate the one employed at Riacho's Farm. The cultivar used was the DKB 390YG sown with $0.76 \mathrm{~m}$ row spacing and 70,000 plants per hectare. Crop fertilization consisted of $300 \mathrm{kgha}^{-1}$ of $10-25-16\left(\mathrm{~N}, \mathrm{P}_{2} \mathrm{O}_{5}\right.$, $\mathrm{K}_{2} \mathrm{O}$ ) formula, plus zinc, applied in sowing furrow, and two $75 \mathrm{kgha}^{-1}$ doses of nitrogen as urea, side-dressed at 20 and 30 days after sowing (DAS). Irrigation was set to be automatically managed, considering a $0.30 \mathrm{~m}$ soil profile control depth and $50 \%$ of available water as critical level for soil-water depletion. Irrigation depths were calculated to bring soil water storage to field capacity. It was also considered that irrigation is uniform and that all applied water infiltrates into the soil.

The model estimates crop evapotranspiration by a modified Priestley-Taylor method (Ritchie, 1998), which calculates soil evaporation separately from transpiration. Water productivity is determined by the grain dry mass yield and crop seasonal evapotranspiration ratio. For each one of the 52 sowing dates, it was generated 46 simulated evapotranspiration and water productivity values, which were plotted as frequency distribution.

Temporal and seasonal simulated crop water requirement and crop water productivity data for irrigated maize, sown at different dates, were analyzed.

\section{RESULTS AND DISCUSSION}

One can note a large seasonal and interannual variability on simulated crop evapotranspiration due to instability of weather elements that affects this trait (Figure 1). The effects can be directly on soil water evaporation and on plant transpiration or indirectly through extending or shortening crop cycle.

The highest median crop evapotranspiration values were observed from December $26^{\text {th }}$ to February $27^{\text {th }}$, coinciding with the highest yield sowing window (Amaral et al., 2011). According Durães and Magalhães (2008), there is a direct relationship between carbon dioxide, oxygen and water vapor exchange between the plant and the atmosphere, reflecting into crop water consumption and grain yield. Median simulated crop cycle evapotranspiration values ranged from 670 to $681 \mathrm{~mm}$ during that period (Figure 1), which is higher than maize baseline value of $600 \mathrm{~mm}$ reported in the literature (Durães; Magalhães, 2008). Older studies indicate maize water requirement values in the order of $543 \mathrm{~mm}$ (Van Bavel, 1961) or between 400 to $700 \mathrm{~mm}$ (Doorenbos; Pruitt, 1977). Detomini et al. (2009), working with high plant populations of DKB 390 hybrid, grown with adequate water and nitrogen supply, found that this maize genotype requires around $600 \mathrm{~mm}$ along its cycle to provide high yields. Simulated water requirement for maize crop, sowed in October $17^{\text {th }}$, which is within the full rainy season in that region of Brazil, but that received supplemental irrigation, was $587.5 \mathrm{~mm}$, $87.0 \mathrm{~mm}$ less than the $674.5 \mathrm{~mm}$ estimated for February $20^{\text {th }}$ sowing week, which corresponds to a water consumption $12.9 \%$ less.

As observed for crop water requirements, one can note a large variability on seasonal and interannual supplemental irrigation depths for maize crop production in the region (Figure 2). Median supplemental irrigation depths varied from $60 \mathrm{~mm}$ for October $17^{\text {th }}$, to $242 \mathrm{~mm}$ for February $20^{\text {th }}$, up to $318.5 \mathrm{~mm}$ for April $24^{\text {th }}$ sowing dates, a significant difference considering water resources use.The decision regarding sowing period, in this case, requires a more accurate analysis, taking into consideration factors such as, farmer's interest, water resources availability, environmental contamination risk and profitability. If there are water 
use restrictions, one would choose the October sowing period that demands less water. On the other hand, if there are no restrictions on water consumption, one would analyze profitability for the different sowing weeks and make a decision based on this information.

The highest simulated water productivity values of 1.73 to $1.81 \mathrm{kgm}^{-3}$ were observed for sowing dates from February $6^{\text {th }}$ to $27^{\text {th }}$ (Figure 3), a period that coincides with the time window that provided the best yields (Amaral et al., 2011). Andrade et al. (2004) determined maize water productivity values varying from 1.22 to $1.74 \mathrm{kgm}^{-3}$, calculated as the ratio between dry grain weight at yield and irrigation plus rainfall depths that maize crop received during its cycle. Mishra et al. (2001) obtained values between 1.39 and $1.54 \mathrm{kgm}^{-3}$ in India, also calculated on the basis of irrigation plus rainfall depths, while Zwart and Bastiaanssen (2004), in a complete literature review, reported maize water productivities ranging from 1.1 to $2.70 \mathrm{kgm}^{-3}$.

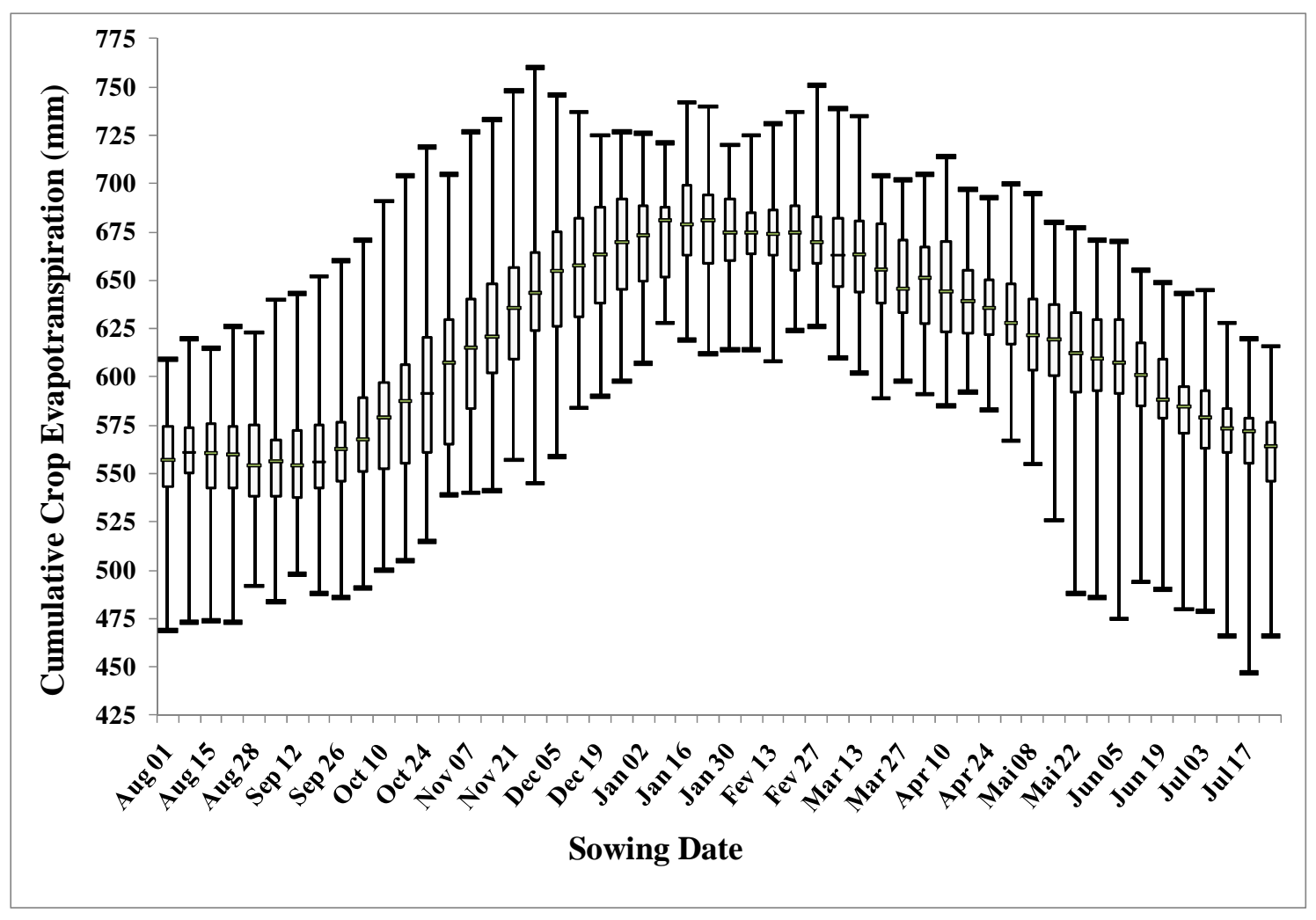

Figure 1. Frequency distribution of crop water requirement indicating minimum, maximum, median and percentiles, for different sowing dates at Riacho Farm, Matozinhos, MG, Brazil. 


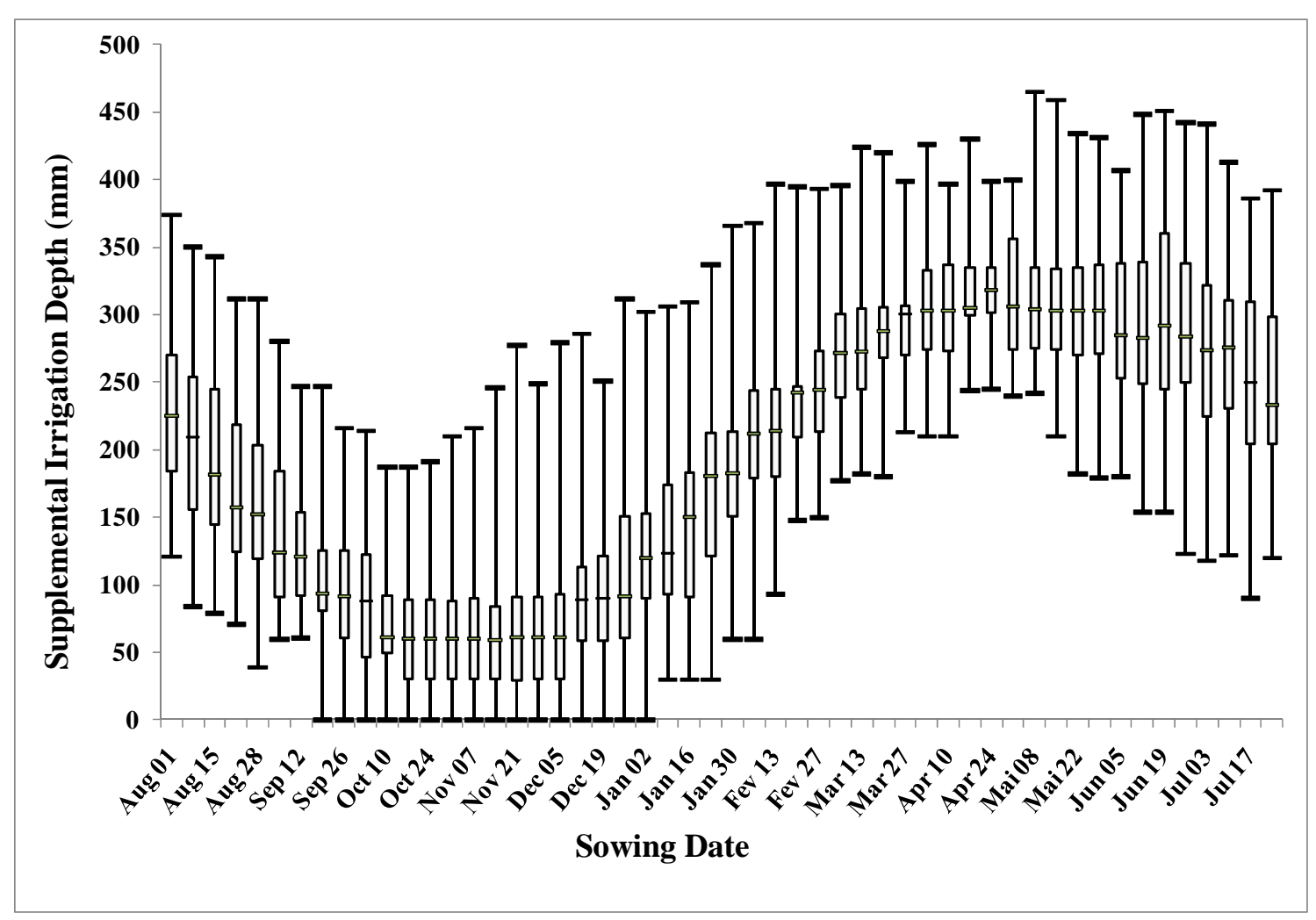

Figure 2. Crop cycle accumulated supplemental irrigation depths, for different sowing dates at Riacho Farm, Matozinhos, MG, Brazil.

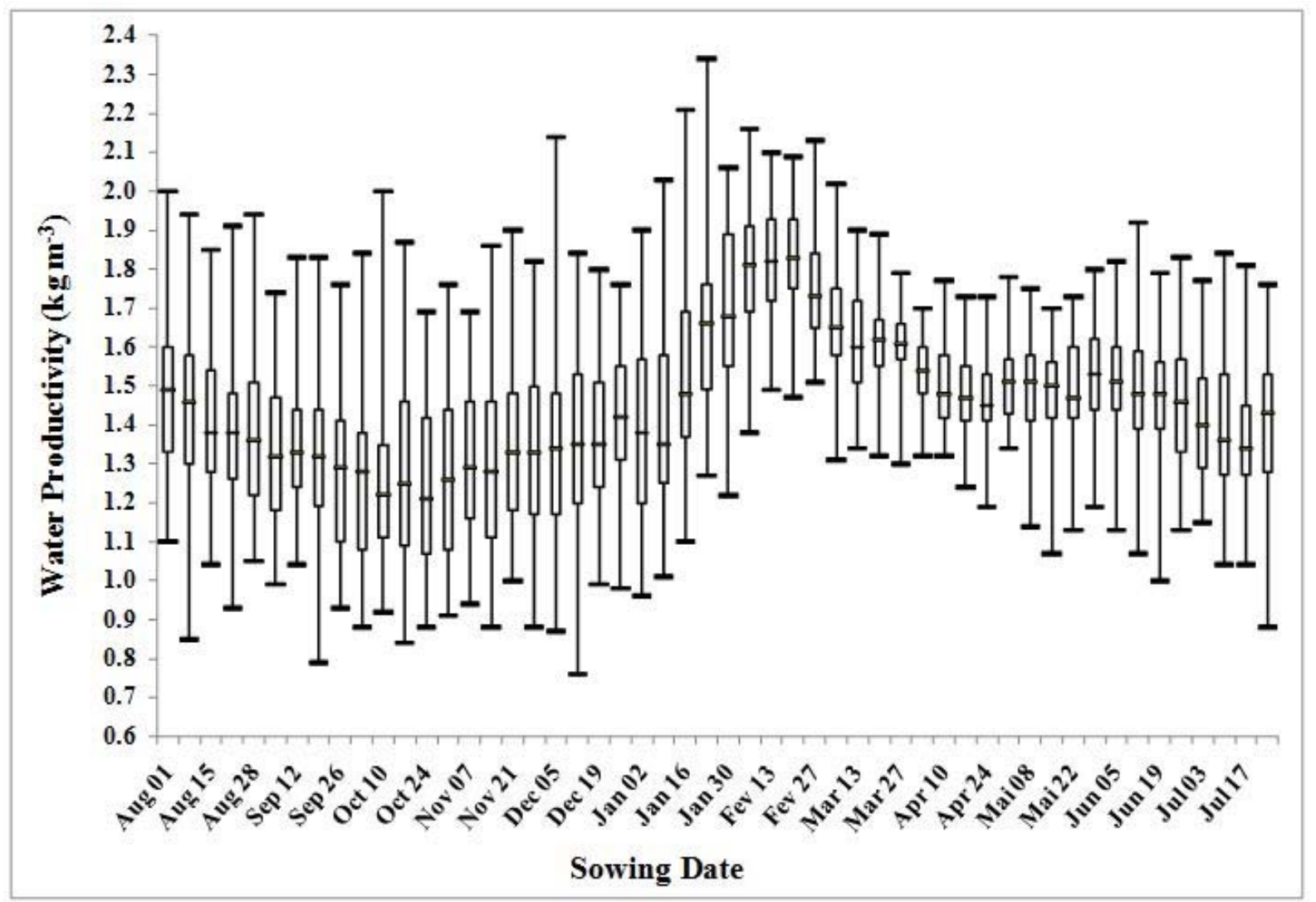

Figure 3. Frequency distribution of maize crop water productivity, for different sowing dates at Riacho Farm, Matozinhos, MG, Brazil. 
The analysis done in this paper is quite important for water resources use planning and management. For water use concession granting and reservoir and irrigation systems design, one should take into account the seasonal and interannual variability of maize regional supplemental irrigation depths requirements. Finally, it is also worth remember that supplemental irrigation use does not guarantee always high yields, since other weather elements, in addition to precipitation, affects maize production performance. Therefore, producers must be prepared to assume the risks inherent to the type of agricultural exploitation. One strategy, which is still being researched and could be used by farmers, would be the yield forecast, allowing for adjustments in the production system to reduce risks and potential economic and environmental losses.

\section{CONCLUSIONS}

The modeling tool is efficient to generate information that can support strategic decisions regarding grain production and water resources use planning in the region. There is a large seasonal and interannual variability in simulated maize crop water requirement and supplemental irrigation depths. The best window, from water resources use point of view, coincides with the sowing period that provides the highest simulated median maize grain yields. Simulations indicates that for February $20^{\text {th }}$ sowing date, maize requires an average of $674.5 \mathrm{~mm}$ of water and $242.0 \mathrm{~mm}$ of supplemental irrigation, while for October $17^{\text {th }}$ sowing, crop water requirement is $587.5 \mathrm{~mm}$ and the supplemental irrigation depth drops to $60.0 \mathrm{~mm}$.

\section{ACKNOWLEDGEMENTS}

The authors would like to express thanks to the State of Minas Gerais Research Support Agency, FAPEMIG, for partially supporting this work through the research grant proposal number EDT 2997/06. We also wish to thank Embrapa, for the personnel and logistics support during data collection, to Mr. Arlindo Marcelo dos Reis, manager of Riacho Farm, for providing data for modeling verification, and to Mr. José dos Santos Evódio, from Minas Gerais State Extension Service Agency, EMATER-MG, for mediating contact with famers.

\section{REFERENCES}

AMARAL, T. A.; ANDRADE, C. L. T.; SILVA, D. F. Applying CSM-CERES-Maize to define a sowing window for irrigated maize crop: the Riacho's farm case study. Ambiente e Água, Taubaté, v. 6, n. 2, p.38-53, 2011. http://dx.doi.org/10.4136/ambi-agua.184

ANDRADE, C. L. T.; ALVARENGA, R. C.; ALBUQUERQUE, P. E. P.; COELHO, A. M.; TEIXEIRA, E. G. Dinâmica de água e soluto em um latossolo cultivado com milho irrigado: 1- percolação e produtividade da água. In: CONGRESSO NACIONAL DE IRRIGAÇÃO E DRENAGEM, 14.; ENCONTRO LATINOAMERICANO DE IRRIGAÇÃO, DRENAGEM E CONTROLE DE ENCHENTES, 1., 2004, Porto Alegre. Anais... Porto Alegre: ABID, 2004. 1 CD-ROM.

CARDOSO, C. O.; FARIA, R. T.; FOLEGATTI, M. V. Aplicação do modelo Ceres-Maize na análise de estratégias de irrigação para milho "safrinha” em Londrina-PR. Engenharia Agrícola, Jaboticabal, v. 24, n. 1, p. 37-45, 2004. 
ANDRADE, C. de L. T. de; AMARAL, T. A.; ALVES, M. E. B.; SILVA, D. F. Temporal variability of the water requirement and productivity for irrigated maize crop. Ambi-Agua, Taubaté, v. 6, n. 2, p. 54-60, 2011. (doi:10.4136/ambi-agua.185)

CENTRAIS ELÉTRICAS DE MINAS GERAIS - CEMIG. Estudo de otimização energética. Belo Horizonte, 1993. 22 p.

DETOMINI, E. R.; MASSIGNAN, L. F. D.; LIBARDI, P. L.; NETO, D. D. Consumo hídrico e coeficiente de cultura para o híbrido DKB 390. Acta Scientiarum Agronomy, Maringá, v. 31, n. 3, p. 445-452, 2009.

DOORENBOS, J.; PRUITT, J. O. Guidelines for predicting crop water requirements. Rome: FAO, 1977. 179 p. (FAO Irrigation and Drainage, 24).

DURÃES, F. O. M.; MAGALHÃES, P. C. Transporte de água no sistema solo-plantaatmosfera: movimento de água e solutos nas plantas. In: ALBUQUERQUE, P. E. P.; DURÃES, F. O. M. (Ed.). Uso e manejo de irrigação. Brasília, DF: Embrapa Informação Tecnológica; Sete Lagoas: Embrapa Milho e Sorgo, 2008. p. 169-224.

HOOGENBOOM, G.; JONES, J. W.; WILKENS, P. W.; PORTER, C. H.; BOOTE, K. J.; HUNT, L. A. et al. In: Decision support system for agrotechnology transfer (DSSAT) version 4.5. Honolulu: University of Hawaii, 2010. 1 CD-ROM.

MISHRA, H. S.; RATHORE, T. R.; SAVITA, U. S. Water-use efficiency of irrigated winter maize under cool weather conditions of India. Irrigation Science, New York, v. 21, p. 27-33, 2001.

PEREIRA, L. S. Indicadores de uso da água. In: CIRELLI, A. F.; ABRAHAM, A. M. (Ed.). Uso y gestión del agua en tierras secas: el agua en Iberoamérica. [S.l.]: CYTED, 2003. v. 11, p. 207-214. Available at: <http://www.cricyt.edu.ar/ladyot/publicaciones/ cyted_2005/PDF/articulos/13_LSP2.pdf>. Access in: January 19, 2011.

RITCHIE, J. T. Soil water balance and plant water stress. In: TSUJI, G. Y.; HOOGENBOOM, G.; THORTHON, P. K. Understanding options for agricultural production. Dordrecht: Kluwer, 1998. p. 41-54. (Systems Approaches For Sustainable Agricultural Development, 7).

SANTANA, C. B.; ANDRADE, C. L. T.; AMARAL, T. A.; SILVA, D. F.; MOURA, B. F.; CASTRO, L. A. Parametrização do modelo Ceres-Maize para cultivares de milho. In: SEMINÁRIO DE INICIAÇÃO CIENTÍFICA PIBIC/BIC JÚNIOR, 1., 2010, Sete Lagoas. Trabalhos apresentados... Sete Lagoas: Embrapa Milho e Sorgo, 2010. 1 CDROM.

VAN BAVEL, C. H. M. Lysimetric measurements of evapotranspiration rates in the eastern United States. Soil Science Society of America Proceedings, Madison, v. 25, p. 138141, 1961.

ZHANG, H. Improving water productivity through deficit irrigation: examples from Syria, the North China plain and Oregon, USA. In: KIJNE, J. W.; BARKER, R.; MOLDEN, D. (Ed.). Water productivity in agriculture: limits and opportunities for improvements. Wallingford: CABI, 2003. cap. 19, p. 301-309.

ZWART, S. J.; BASTIAANSSEN, W. G. M. Review of measured crop water productivity values for irrigated wheat, rice, cotton and maize. Agricultural Water Management, Amsterdam, v. 69, p. 115-133, 2004. http://dx.doi.org/10.1016/j.agwat.2004.04.007 